\title{
Supplemental effects of biofloc powder on growth performance, innate immunity, and disease resistance of Pacific white shrimp Litopenaeus vannamei
}

\author{
Chorong Lee', Soohwan Kim', Se-Jin Lim² and Kyeong-Jun Lee ${ }^{1 *}$
}

\begin{abstract}
An 8-week feeding trial was conducted to study the effect of dietary supplementation of a biofloc powder on growth performance and non-specific immune response of Litopenaeus vannamei. Seven experimental diets were prepared with supplementation of graded levels of dried biofloc powder by $0,0.5,1.0,2.0,4.0,6.0$, and $8.0 \%$ (designated as Con, BF0.5, BF1, BF2, BF4, BF6, and BF8, respectively). Triplicate groups of shrimp (1.01 $\pm 0.01 \mathrm{~g})$ were hand-fed with one of the diets four times a day. At the end of the feeding trial, significantly $\left(P^{<} 0.05\right)$ higher growth performance and feed utilization were obtained in BF4 groups compared to those fed the Con diet. The innate immunity of shrimp was improved by the dietary supplementation of biofloc. Dietary inclusion of biofloc at the level of 4.0\% significantly increased disease resistance of shrimp against Vibrio harveyi. The results indicate that biofloc might be used as a dietary supplement for growth performance, innate immunity and disease resistance of Pacific white shrimp.
\end{abstract}

Keywords: Biofloc powder, Innate immunity, Growth performance, Disease resistance, Litopenaeus vannamei

\section{Background}

Diseases caused by infectious microorganisms are known to be one of the major constraints in the shrimp aquaculture industry for the past decades (Ekasari et al., 2014). Thus, there is a need to control the disease outbreaks in this sector. A concept of a functional feed is an emerging paradigm in aquaculture industry to develop nutritionally balanced diets with functions to control the diseases and culture water system by feed additives ( $\mathrm{Li}$ and Gatlin 2004; Lee et al., 2013; Wongsasak et al., 2015).

The application of biofloc technology (BFT) in shrimp aquaculture has gained great attention. BFT offers a practical solution to control culture water quality effectively with negligible water exchange and improves shrimp growth performances in the healthy culture environment (De Schryver et al., 2008; Stokstad, 2010; Avnimelech, 2012; Crab et al., 2012; Xu and Pan 2013). The mechanism of the BFT is to

\footnotetext{
* Correspondence: kjlee@jejunu.ac.kr

${ }^{1}$ Department of Marine Life Sciences, Jeju National University, Jeju 63243,

South Korea

Full list of author information is available at the end of the article
}

reuse excreted dissolved nitrogen by heterotrophic bacteria by controlling carbon and nitrogen ratio in the culture water (Avnimelech, 1999). The biofloc in the BFT system is formed by aggregating many substances such as, other microorganisms, microalgae, zooplankton, and trapped organic particles or solids from uneaten feeds (De Schryver et al., 2008; Crab et al., 2012; Ekasari et al., 2014). It has been demonstrated that the active and condensed microorganisms together with suspended organic or inorganic particles tend to from biofloc, which can be consumed constantly by cultured shrimp as a natural food source (Burford et al., 2004; Wasielesky et al., 2006; Kent et al., 2011). Thus, the biofloc itself provides biomass which is served as nutrients for shrimp especially as a protein source or immunostimulants. Previous studies showed that biofloc had enhanced cellular immune response and antioxidant status of cultured shrimp by its richness in microbes and bioactive compounds (Ju et al., 2008; Xu and Pan 2013). Similar result was found when $L$. vannamei were fed a formulated 35\% crude protein diet in biofloc-based culture tanks for a period of 30 days; however, it is not clear if 
feeding a relatively low protein diet (35\%) with the contribution of biofloc could sustain the health status of cultured shrimp in such systems (Xu and Pan 2013). Jang et al. (2011) also reported that the expression of prophenoloxidase-activating enzyme was significantly increased in the shrimp reared in a biofloc system.

Pacific white shrimp is one of the most important shrimp species currently being cultured in many countries. Over the past decade, mass production of $L$. vannamei has been demonstrated in biofloc-based intensive culture systems under high aeration and negligible water exchange (Avnimelech, 2012; Haslun et al., 2012). Recently, it was demonstrated that dietary inclusion of biofloc had enhanced growth performance of $L$. vannamei (Ju et al., 2008; Kuhn et al., 2010; Bauer et al., 2012). There is a lack of information to support the role of biofloc in diets on growth and immune response in the species. Hence, to investigate the suitability of biofloc as a dietary supplement, we included it in diets at different levels and fed to $L$. vannamei. The present study aims to evaluate the effect of dietary supplementation of biofloc on growth performance, non-specific immune response, and susceptibility to bacterial infection caused by $V$. harveyi in $L$. vannamei juveniles.

\section{Methods}

\section{Preparation of biofloc}

The biofloc was collected from L. vannamei BFT tanks. A biofloc suspension was prepared in a 300 ton polypropylene tank $(45 \times 6.5 \mathrm{~m})$ filled with seawater and stocked with L. vannamei. The C: $\mathrm{N}$ ratio was maintained at 15:1 using molasses as a carbon source. Probiotics containing Bacillus subtilis, Lactobacillus casei and Saccharomyces cerevisiae (Total bacterial account $=1 \times 10^{6} \mathrm{CFU} / \mathrm{mL}$ ) were added into the biofloc ponds once a week until enough biofloc sample was collected. Biofloc collection was continued for $12 \mathrm{~h}$ with enough and strong aeration in the BFT tanks. During the aeration, sludges (flocs) were formed on the water surface. The collected flocs were rapidly frozen at $-80{ }^{\circ} \mathrm{C}$, and then vacuum freeze-dried. The dried flocs were ground into fine powder $(<100 \mu \mathrm{m})$ and kept in airtight containers in refrigerator until used in experimental diets. Chemical composition of the biofloc powder is provided in Table 1.

\section{Experimental diets and design}

Seven experimental diets were formulated to be isonitrogenous (400 $\mathrm{g} \mathrm{kg}^{-1}$ crude protein) and isocaloric (16 MJ kg

${ }^{-1}$ ). A basal fishmeal based diet was regarded as a control and supplemented with biofloc at the incremental levels of 0.5, 1.0, 2.0, 4.0, 6.0, and 8.0\% (designated as Con, BF0.5, $\mathrm{BF} 1, \mathrm{BF} 2, \mathrm{BF} 4, \mathrm{BF} 6$, and BF8, respectively) at the expense of soybean meal and wheat flour. All dry ingredients were thoroughly mixed in a feed mixer (NVM-16, Gyeonggido,
Table 1 Biofloc chemical composition (dry matter)

\begin{tabular}{ll}
\hline Parameter & Biofloc \\
\hline Proximate composition & $(\%)$ \\
Crude protein & 28.7 \\
Crude lipid & 2.30 \\
Crude ash & 43.0 \\
Amino acid composition & $(\%)$ \\
Methionine & 0.36 \\
Arginine & 1.17 \\
Phenylalanine & 1.16 \\
Leucine & 1.81 \\
Isoleucine & 1.02 \\
Lysine & 1.11 \\
Valine & 1.51 \\
Threonine & 1.31 \\
Histidine & 0.41 \\
Trace mineral composition & $(\mathrm{mg} / \mathrm{kg})$ \\
Zinc & 521.8 \\
Aluminum & 287.8 \\
Manganese & 180.7 \\
Iron & 146.9 \\
Copper & 34.0 \\
Aluminum silicate & 3.4 \\
\hline & 2.7 \\
\hline
\end{tabular}

South Korea) and pelleted through a pellet machine (SP-50; Gumgang Engineering, Daegu, Korea). The pelleted diets were dried at $25{ }^{\circ} \mathrm{C}$ for $12 \mathrm{~h}$, and stored at $-24{ }^{\circ} \mathrm{C}$ until used. Formulation and proximate composition of the experimental diets are shown in Table 2.

\section{Shrimp and feeding trial}

The feeding trial was conducted in indoor shrimp culture facilities at the Marine Science Institute of the Jeju National University (Jeju, South Korea). Juvenile L. vannamei was obtained from NeoEnBiz shrimp farm (Dangjin, South Korea). Shrimps were fed a commercial diet (35\% crud protein) twice daily for 10 days to be acclimated to the experimental conditions and facilities. Then, the shrimps (initial mean body weight, $1.01 \pm 0.01 \mathrm{~g}$ ) were randomly distributed into twenty one acryl aquaria of $96 \mathrm{~L}$ capacity at a density of 18 shrimp per aquarium. Each aquarium was supplied with filtered seawater and aeration to maintain enough dissolved oxygen. Triplicate groups of shrimp were hand-fed with one of the test diets four times a day at $08: 00,12.00,16.00$, and 18:00 h for 8 weeks. Daily feeding rates were slowly reduced from 10 to $8 \%$ of wet body weight during the 8-week feeding period. Water in the aquaria was exchanged every 3-day intervals while inside of the aquaria were cleaned by a sponge to prevent 
Table 2 Dietary formulation and proximate composition of the seven experimental diets for L. vannamei (\% dry matter)

\begin{tabular}{|c|c|c|c|c|c|c|c|}
\hline \multirow[t]{2}{*}{ Ingredients } & \multicolumn{7}{|c|}{ Experimental diets } \\
\hline & Con & BF0.5 & BF1 & $\mathrm{BF} 2$ & BF4 & BF6 & BF8 \\
\hline Brown fishmeal & 28.0 & 28.0 & 28.0 & 28.0 & 28.0 & 28.0 & 28.0 \\
\hline Soybean meal & 30.0 & 30.0 & 30.0 & 29.5 & 28.5 & 27.5 & 26.5 \\
\hline Squid liver meal & 3.00 & 3.00 & 3.00 & 3.00 & 3.00 & 3.00 & 3.00 \\
\hline Wheat flour & 29.0 & 28.5 & 28.0 & 27.5 & 26.5 & 25.5 & 24.5 \\
\hline Starch & 5.00 & 5.00 & 5.00 & 5.00 & 5.00 & 5.00 & 5.00 \\
\hline Fish oil & 1.00 & 1.00 & 1.00 & 1.00 & 1.00 & 1.00 & 1.00 \\
\hline Mineral mix ${ }^{a}$ & 1.00 & 1.00 & 1.00 & 1.00 & 1.00 & 1.00 & 1.00 \\
\hline Vitamin mix ${ }^{b}$ & 1.00 & 1.00 & 1.00 & 1.00 & 1.00 & 1.00 & 1.00 \\
\hline Choline chloride & 1.00 & 1.00 & 1.00 & 1.00 & 1.00 & 1.00 & 1.00 \\
\hline Lecithin & 1.00 & 1.00 & 1.00 & 1.00 & 1.00 & 1.00 & 1.00 \\
\hline Biofloc & 0.00 & 0.50 & 1.00 & 2.00 & 4.00 & 6.00 & 8.00 \\
\hline \multicolumn{8}{|c|}{ Chemical composition (\% dry matter) } \\
\hline Dry matter & 93.2 & 93.8 & 94.0 & 93.2 & 93.1 & 93.6 & 93.5 \\
\hline Crude protein & 40.8 & 40.9 & 40.7 & 40.6 & 41.0 & 41.0 & 41.0 \\
\hline Crude lipid & 6.70 & 7.50 & 7.10 & 7.00 & 7.60 & 7.30 & 7.50 \\
\hline Crude Ash & 8.00 & 8.40 & 8.30 & 8.60 & 9.30 & 10.0 & 10.8 \\
\hline Energy, MJ/kg diet & 16.6 & 16.6 & 16.6 & 16.5 & 16.4 & 16.2 & 16.1 \\
\hline
\end{tabular}

${ }^{a}$ Mineral premix (g/kg mixture): $\mathrm{MgSO}_{4} .7 \mathrm{H}_{2} \mathrm{O}, 80.0 ; \mathrm{NaH}_{2} \mathrm{PO}_{4} .2 \mathrm{H}_{2} \mathrm{O}, 370.0 ; \mathrm{KCl}$ 130.0; Ferric citrate, 40.0; $\mathrm{ZnSO}_{4} .7 \mathrm{H}_{2} \mathrm{O}, 20.0$; Ca-lactate, 356.5; $\mathrm{CuCl}$, 0.2; $\mathrm{AlCl}_{3} .6 \mathrm{H}_{2} \mathrm{O}, 0.15 ; \mathrm{Na}_{2} \mathrm{Se}_{2} \mathrm{O}_{3}, 0.01 ; \mathrm{MnSO}_{4} \cdot \mathrm{H}_{2} \mathrm{O}, 2.0 ; \mathrm{CoCl}_{2} .6 \mathrm{H}_{2} \mathrm{O}, 1.0$

${ }^{\mathrm{b}}$ Vitamin premix (g/kg mixture): L-ascorbic acid, 121.2; DL-tocopheryl acetate, 18.8; thiamin hydrochloride, 2.7; riboflavin, 9.1; pyridoxine hydrochloride, 1.8; niacin, 36.4; Ca-p-pantothenate, 12.7; myo-inositol, 181.8; D-biotin, 0.27; folic acid, 0.68; $\mathrm{p}$-aminobezoic acid, 18.2; menadione, 1.8 ; retinyl acetate, 0.73 ; cholecalficerol, 0.003; cyanocobalamin, 0.003

the growth of microflora. A 12:12 h light/dark regime (08:00-19:00 h, light period) was maintained by timed fluorescent lighting. The water temperature was maintained at $28 \pm 1{ }^{\circ} \mathrm{C}$, pH ranged from 7.04 to 8.04 , and dissolved oxygen was kept above $6.0 \mathrm{mg} \mathrm{L}^{-1}$ and total ammonia nitrogen and nitrite were kept $<0.1$ and $0.005 \mathrm{mg} \mathrm{L}^{-1}$, respectively. Growth of shrimp was measured with 2-week intervals. Feeding was stopped $16 \mathrm{~h}$ prior to weighing or hemolymph sampling to minimize handling stress on the shrimp.

\section{Sample collection and analyses}

At the end of the feeding trial, all shrimp in each tank were counted and bulk-weighed for calculation of growth parameters and survival. Five shrimp per tank (fifteen shrimp per dietary treatment) in inter-molt stage were randomly captured, anesthetized with ice-cold water and hemolymph samples $(200 \mu \mathrm{l})$ were individually collected from ventral sinus of shrimp using a 1-mL syringe. Then, the hemolymph $(200 \mu \mathrm{L})$ was filled with an equal volume of anticoagulant solution $(200 \mu \mathrm{L})$ (Alsever's solution, Sigma). The molt stage of the shrimp was determined by an examination of uropoda
(Robertson et al., 1987). The hemolymph-anticoagulant mixture (diluted hemolymph) was placed in five sterile eppendorf tubes containing equal volume for the determination of the total hemocyte counts (THC) and respiratory burst activity. After the abovementioned measurements with diluted hemolymph, the remained samples was centrifuged at $800 \times g$ for $20 \mathrm{~min}$ using a high-speed refrigerated microcentrifuge (Micro 17 TR; HanilBioMed Inc., Gwangju, Korea) and stored at $-70{ }^{\circ} \mathrm{C}$ for determination of phenoloxidase (PO), superoxide dismutase (SOD) activities, total immunoglobulin (Ig) level and glutathione peroxidase (GPx) activity.

Analyses of moisture and ash contents of biofloc powder and diet samples were performed by the standard procedures (AOAC, 1995). Crude protein was measured by using an automatic Kjeltec Analyzer Unit 2300 (Foss Tecator, Höganäs, Sweden), and crude lipid was determined using the Soxhlet method with extraction in diethyl ether (Soxhlet Extraction System C-SH6, Korea).

\section{Monitoring of non-specific immune responses}

A drop of the diluted haemolymph was placed in a hemocytometer to measure THC using an inverted phasecontrast microscope (Olympus, Model CH30RF200, Olympus Optical Co., LTD, Japan). Diluted hemolymph protein content was measured using a microprotein determination method (C-690; Sigma). Oxidative radical production by hemocytes during respiratory burst was measured through the nitro blue tetrazolium (NBT) assay described by Dantzler et al. (2001). PO activity was measured spectrophotometrically by recording the formation of dopachrome produced from L-dihydroxyphenylalanine (L-DOPA, Sigma) following the procedure of HernándezLópez et al. (1996). Lysozyme activity was determined following previously described method (Paglia and Valentine, 1967). SOD activity was measured by the percentage reaction inhibition rate of enzyme with WST-1 (water-soluble tetrazolium dye) substrate and xanthine oxidase using a SOD Assay Kit (Sigma, 19160) according to the manufacturer's instructions. Each endpoint assay was monitored by absorbance at $450 \mathrm{~nm}$ (the absorbance wavelength for the colored product of WST-1 reaction with superoxide) after 20 min of reaction time at $37^{\circ} \mathrm{C}$. The percent inhibition was normalized by $\mathrm{mg}$ protein and presented as SOD activity units. Ig level was determined according to the method described by Siwicki et al. (1994). Briefly, plasma total protein content was measured using a microprotein determination method (C-690; Sigma), prior to and after precipitating down the Ig molecules, using a $12 \%$ solution of polyethylene glycol (Sigma). The difference in protein content represents the Ig content. GPX activity was assayed using a kit (Biovision, Inc., Milpitas, CA, USA). 


\section{Challenge test}

At the end of the feeding trial, 12 shrimp from each tank (24 shrimp per treatment) were randomly selected and subjected to a bacterial challenge. $V$. harveyi was used as the pathogenic agent (provided by the Marine Microbiology Laboratory of Jeju National University). The shrimp were injected intramuscularly with $V$. harveyi suspension containing $2 \times 10^{8} \mathrm{CFU} \mathrm{mL} \mathrm{m}^{-1}$ and distributed into fourteen 120-L acryl tanks. The pathogenic dose of bacterium had previously been determined in a preliminary test using similar size of shrimp. After injection, the challenging shrimp was not fed the diets and the mortality was monitored for 19 days.

\section{Statistical analysis}

All dietary treatments were assigned by a completely randomized design. Data were subjected to one-way analysis of variance (ANOVA) in SPSS version 12.0 (SPSS Inc., Chicago, IL, USA). When ANOVA identified differences among groups, the difference in means was made with LSD multiple range tests. Statistical significance was determined at $P<0.05$. Data are presented as mean \pm SD. Percentage data were arcsine transformed before analysis.

\section{Results}

Growth performance and feed utilization of the shrimp were significantly affected by dietary supplementation of the biofloc compared to those of shrimp fed the Con diet (Table 3). Final body weight, weight gain and specific growth rate of shrimp fed BF4 diet were significantly increased compared to those fed the Con diet. Dietary inclusion of the biofloc to the Con diet at level of $4.0 \%$ resulted in significantly higher protein efficiency ratio (PER) and lower feed conversion ratio (FCR) compared to the Con diet. Significantly higher feed intake (FI) was observed in shrimp fed the Con diet than in that fed the BF8 diet. The highest survival rate was obtained in BF0.5 group which was significantly different from other dietary groups.

Shrimp fed BF0.5 and BF4 diets showed significantly higher NBT activity than shrimp fed the Con diet (Table 4). Significantly higher PO activity was found in shrimp fed BF6 diet than those fed the Con diet. Significant increment in GPx activity was observed in BF6 groups in comparison to the Con group. Even though numerically higher values of other examined nonspecific immune parameters were observed in shrimp fed the biofloc supplemented diets, the differences were not significant $(P>0.05)$.

During the challenge test, the first dramatic mortality was observed on the 13th day after injection and shrimp fed the Con diet showed the lowest disease resistance compared to all other groups (Fig. 1). At the end of the challenge test, significantly higher survival rate was found in BF4 group compared to the Con groups; however, no significant difference was found among other biofloc supplemented groups.

\section{Discussion}

Beneficial role of BFT system in penaeid shrimp has well been documented (Hari et al., 2006; Xu and Pan 2012). Recently, it was reported that use of biofloc as a dietary supplement had enhanced growth rate of $L$. vannamei (Ju et al., 2008; Kuhn et al., 2009, 2010). In the present study, dietary supplementation of biofloc at $4 \%$ level significantly $(P<0.05)$ enhanced growth, PER and FCR in the shrimp. It has been documented that bioflocs are the rich source of many bioactive compounds, such as carotenoids, chlorophylls, phytosterols, bromophenols, amino sugars (Ju et al., 2008) and anti-bacterial compounds (Crab et al., 2010). Thus, the enhanced growth performance of shrimp fed the biofloc containing diet in the

Table 3 Growth performance and feed utilization of L. vannamei (initial BW: $1.01 \pm 0.01 \mathrm{~g}$ ) fed the seven experimental diets for 8 weeks

\begin{tabular}{|c|c|c|c|c|c|c|c|}
\hline Treatment & $\mathrm{FBW}^{1}$ & $W G^{2}$ & $S G R^{3}$ & $F C R^{4}$ & $\mathrm{PER}^{5}$ & $\mathrm{Fl}^{6}$ & Survival $^{7}$ \\
\hline Con & $6.63 \pm 0.55^{b}$ & $565 \pm 49.6^{b}$ & $3.32 \pm 0.13^{b}$ & $2.25 \pm 0.21^{a}$ & $1.10 \pm 0.11^{b}$ & $12.8 \pm 0.13^{\mathrm{a}}$ & $79.6 \pm 16.0^{b}$ \\
\hline BF0.5 & $7.12 \pm 0.44^{\mathrm{ab}}$ & $610 \pm 41.5^{\mathrm{ab}}$ & $3.44 \pm 0.10^{\mathrm{ab}}$ & $2.09 \pm 0.16^{\mathrm{ab}}$ & $1.15 \pm 0.09^{\mathrm{ab}}$ & $12.8 \pm 0.02^{\mathrm{ab}}$ & $98.1 \pm 3.21^{a}$ \\
\hline BF1 & $7.12 \pm 0.82^{\mathrm{ab}}$ & $608 \pm 70.2^{\mathrm{ab}}$ & $3.43 \pm 0.17^{\mathrm{ab}}$ & $2.10 \pm 0.25^{\mathrm{ab}}$ & $1.18 \pm 0.15^{\mathrm{ab}}$ & $12.8 \pm 0.01^{\mathrm{ab}}$ & $85.2 \pm 8.49^{b}$ \\
\hline BF2 & $7.34 \pm 0.71^{\mathrm{ab}}$ & $635 \pm 67.5^{\mathrm{ab}}$ & $3.50 \pm 0.16^{\mathrm{ab}}$ & $2.01 \pm 0.22^{\mathrm{ab}}$ & $1.24 \pm 0.13^{\mathrm{ab}}$ & $12.7 \pm 0.01^{\mathrm{ab}}$ & $88.9 \pm 0.00^{b}$ \\
\hline BF4 & $7.90 \pm 0.13^{a}$ & $677 \pm 8.40^{a}$ & $3.60 \pm 0.02^{a}$ & $1.84 \pm 0.04^{b}$ & $1.32 \pm 0.03^{\mathrm{a}}$ & $12.7 \pm 0.04^{\mathrm{ab}}$ & $85.2 \pm 3.21^{b}$ \\
\hline BF6 & $7.27 \pm 0.81^{\mathrm{ab}}$ & $627 \pm 81.4^{\mathrm{ab}}$ & $3.47 \pm 0.19^{\mathrm{ab}}$ & $2.05 \pm 0.27^{\mathrm{ab}}$ & $1.20 \pm 0.16^{\mathrm{ab}}$ & $12.7 \pm 0.04^{\mathrm{ab}}$ & $88.9 \pm 5.56^{b}$ \\
\hline BF8 & $7.56 \pm 0.38^{\mathrm{ab}}$ & $639 \pm 39.8^{\mathrm{ab}}$ & $3.51 \pm 0.10^{\mathrm{ab}}$ & $1.91 \pm 0.15^{\mathrm{ab}}$ & $1.28 \pm 0.10^{\mathrm{ab}}$ & $12.5 \pm 0.48^{b}$ & $90.7 \pm 6.42^{b}$ \\
\hline
\end{tabular}

Values are mean of triplicate groups and presented as mean \pm SD. Values in the same column having different letters are significantly different $(\mathrm{LSD} ; P<0.05)$

${ }^{1} \mathrm{FBW}(\mathrm{g})=$ Final body weight

${ }^{2}$ Weight gain $(\%)=[($ final body weight - initial body weight)/initial body weight $] \times 100$

${ }^{3}$ Specific growth rate $(\%)=100 \times[\ln ($ final body weight $)-\ln$ (initial body weight) $] /$ days

${ }^{4}$ Feed conversion ratio $=$ dry feed fed/wet weight gain

${ }^{5}$ Protein efficiency ratio $=$ fish weight gain $(\mathrm{g}) /$ protein

${ }^{6}$ Feed intake $(\mathrm{g} / \mathrm{fish})=$ dry feed consumed $(\mathrm{g}) / \mathrm{fish}$

${ }^{7}$ Survival (\%) 
Table 4 Non-specific immune responses of L. vannamei fed the seven experimental diets for 8 weeks

\begin{tabular}{|c|c|c|c|c|c|c|}
\hline Treatment & $\mathrm{THC}^{1}$ & $\mathrm{NBT}^{2}$ & $\mathrm{PO}^{3}$ & $\mathrm{SOD}^{4}$ & $\lg ^{5}$ & $G P x^{6}$ \\
\hline$\overline{C o n}$ & $0.33 \pm 0.01$ & $0.27 \pm 0.04^{b}$ & $0.16 \pm 0.01^{b}$ & $238 \pm 18.6$ & $31.2 \pm 12.7$ & $107 \pm 37.7^{b}$ \\
\hline BF0.5 & $1.95 \pm 1.30$ & $0.32 \pm 0.00^{a}$ & $0.18 \pm 0.02^{b}$ & $240 \pm 3.56$ & $44.9 \pm 13.6$ & $133 \pm 32.4^{\mathrm{ab}}$ \\
\hline BF1 & $4.14 \pm 0.52$ & $0.28 \pm 0.03^{\mathrm{ab}}$ & $0.17 \pm 0.02^{b}$ & $235 \pm 30.8$ & $30.6 \pm 4.12$ & $181 \pm 25.4^{\mathrm{ab}}$ \\
\hline BF2 & $2.26 \pm 0.71$ & $0.28 \pm 0.02^{\mathrm{ab}}$ & $0.18 \pm 0.02^{b}$ & $254 \pm 15.0$ & $38.1 \pm 6.97$ & $157 \pm 45.3^{a b}$ \\
\hline BF4 & $4.52 \pm 3.81$ & $0.32 \pm 0.04^{a}$ & $0.16 \pm 0.03^{b}$ & $249 \pm 12.0$ & $39.6 \pm 6.29$ & $184 \pm 76.5^{a b}$ \\
\hline BF6 & $3.12 \pm 1.46$ & $0.29 \pm 0.02^{\mathrm{ab}}$ & $0.24 \pm 0.04^{\mathrm{a}}$ & $250 \pm 37.5$ & $43.6 \pm 18.3$ & $205 \pm 55.3^{\mathrm{a}}$ \\
\hline BF8 & $4.40 \pm 4.29$ & $0.31 \pm 0.03^{\mathrm{ab}}$ & $0.18 \pm 0.04^{b}$ & $246 \pm 9.13$ & $37.4 \pm 2.69$ & $159 \pm 40.9^{a b}$ \\
\hline
\end{tabular}

Values are mean of triplicate groups and presented as mean \pm SD. Values in the same column having different letters are significantly different (LSD; $P<0.05)$

${ }^{1}$ Total haemocyte count $\left(10^{3}\right.$ cells $\left./ \mathrm{mL}\right)$

${ }^{2}$ Nitro blue tetrazolium activity

${ }^{3}$ Phenoloxidase activity

${ }^{4}$ Superoxide dismutase (\% inhibition)

${ }^{5}$ Total immunoglobulin $\left(\mathrm{mg} \mathrm{mL}^{-1}\right)$

${ }^{6}$ Glutathione peroxidase activity $\left(\mathrm{mU} \mathrm{mL}^{-1}\right)$

current study might be explained by a bioactive or probiotic microbial components, such as Bacillus or Lactobacillus spp. present in the biofloc. On the other hand, biofloc supplementation at $8 \%$ level (BF8) did not result in proportionate enhancement in growth rate or FCR compared to those of the Con diet. Kuhn et al. (2010) supplemented a biofloc in L. vannamei diet and recorded significantly higher growth rate at 10 and $15 \%$, but no significant difference at 20 and 30\% dietary biofloc inclusion. The present results also agree with those of Wang (2007) and Anand et al. (2013) who reported that increment of dietary probiotic or periphytic algae in shrimp does not proportionally increase growth performance of shrimp. Moreover, reduction in growth of fishes was recorded at high level of microbial supplementation (Kiessling and Askbrandt 1993; Ajiboye et al., 2012) as microbial products at higher levels tend to reduce feed palatability and digestibility (Kiessling and Askbrandt 1993). However, the growth performance of
BF6 and BF8 in the present study were comparable or relatively higher compared to the Con diet, indicating non negative growth effects in shrimp by the dietary biofloc supplementation up to $8 \%$.

Shrimp lack specific or adaptive immune system that relies entirely on their innate immune mechanisms including both cellular and humoral responses for defense against pathogens (Vazquez et al., 2009). NBT activity was increased in the shrimp fed BF0.5 and BF4, while significantly higher PO activity was observed in BF6 group compared to those fed the Con diet. It was suggested that shrimp may release some useful substances into gastrointestinal tract that could potentially stimulate innate immune response (especially phagocytosis) and may release more hemocytes into their circulation when they ingested biofloc (Zhao et al., 2012). Some beneficial bacteria such as Bacillus $s p$. in the ingested biofloc could have facilitate modification of physiological and immunological status of the host through a colonization in the gastrointestinal tract and have

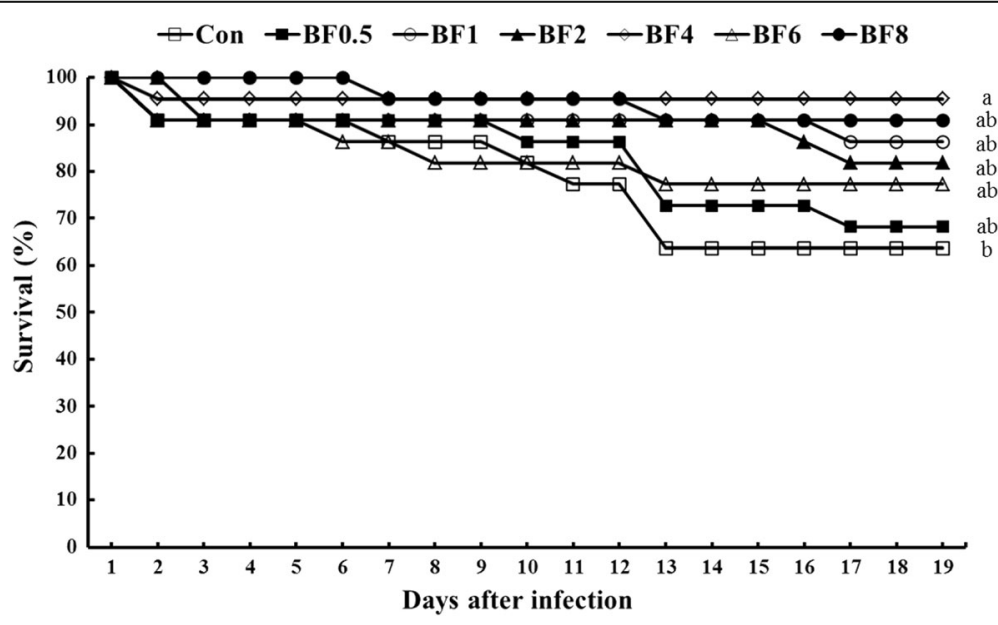

Fig 1 Survival rate of $L$. vannamei after a challenge against $V$. harveyi 
triggered to change the endogenous microbiota (Johnson et al., 2008; Li et al., 2009). Ju et al. (2008) noted that both microbial components (Bacillus sp.) and bioactive compounds (e.g., polysaccharides and carotenoids) in biofloc could exert an immune-stimulating effect and this action would be continuous as long as the shrimp consumes biofloc. However, the modes of action of biofloc on innate immune mechanism of shrimp are very complicated and still unknown up to date. Further study is required for more detailed information and knowledge on this. Research on antioxidants has been attracted in aquaculture because fish or shrimp are susceptible to oxidative stress by disease or environmental changes (Liu and Chen, 2004; Castex et al., 2010). Shrimp possess an integrated antioxidant system including enzymatic and non-enzymatic antioxidants to maintain normal oxidant status, especially to cope with natural or induced stressors (Castex et al., 2009; Parrilla-Taylor and Zenteno-Savín, 2011). Generally, the antioxidant capability of an organism under certain condition can reflect its health status. In the present study, increased GPx activity was observed in shrimp fed BF6 diet compared to those fed the Con diet. This result indicates that the antioxidant system of the shrimp can be enhanced by unknown components present in biofloc in some way. Based on its composition characteristics, the biofloc may play a role in antioxidant activity because of its carotenoids and fatsoluble vitamins (Ju et al., 2008) and improve the efficiency of feed utilization by stimulating activities of digestive enzymes because of high protease and amylase activity in biofloc (Xu and Pan 2012; Xu et al. 2012). Similarly, Xu and Pan (2013) reported an increase in total antioxidant capacity and SOD activity of L. vannamei reared in a bioflocbased tanks system.

During the challenge test against $V$. harveyi, significantly higher survival rate was found in BF4 group compared to the Con group. Similar observations were found by Ekasari et al. (2014) where following a challenge test by injection with infectious myonecrosis virus (IMNV) the survival of the challenged shrimp from the experimental biofloc groups was significantly higher when compared to the challenged shrimp from the control treatment.

\section{Conclusions}

This study indicates that dietary supplementation of a good source of biofloc at $4 \%$ level had beneficial effects on growth performance and health status in L. vannamei. The concurrent increases of non-specific responses of the shrimp fed the biofloc supplemented diets may suggest that the antioxidant defense system and innate immune system could work synergistically to improve the physiological performance of the shrimp leading to higher disease resistance against bacterial challenge. These results also indicate that the biofloc could be practically used as a viable alternative dietary supplement. It seems clear that the potential use of biofloc as a dietary supplement would be dependent upon the process method of the biofloc and the quantity of organic compounds and beneficial microorganism.

\section{Abbreviations \\ BFT: Biofloc technology; FCR: Feed conversion ratio; Fl: Feed intake; GPx: Glutathione peroxidase; Ig: Total immunoglobulin; NBT: Nitro blue tetrazolium; PER: Protein efficiency ratio; PO: Phenoloxidase; SOD: Superoxide dismutase; THC: Total hemocyte counts}

\section{Acknowledgements}

This research was supported by the Korea Ministry of Oceans and Fisheries, which provided federal funds to support the "Development of functional feed additives for shrimp using useful organic matter in biofloc-based rearing water."

\section{Funding}

This study was funded by the Korea Ministry of Oceans and Fisheries, which provided federal funds to support the "Development of functional feed additives for shrimp using useful organic matter in biofloc-based rearing water."

Availability of data and materials

All datasets analyzed during the current study are available from the corresponding author on reasonable request.

\section{Authors' contributions}

$\mathrm{CR}$ and $\mathrm{SH}$ conducted the feeding trial, analysis, and drafted the manuscript. SJ manufactured the experimental diet. KJ designed this study, led in analyzing data derived from this study, and revised the manuscript. All authors read and approved the final manuscript.

\section{Ethics approval and consent to participate}

Experimental protocols followed the guidelines of the Animal Care and Use Committee of Jeju National University.

Consent for publication

Not applicable.

\section{Competing interests}

The authors declare that they have no competing interests.

\section{Author details}

'Department of Marine Life Sciences, Jeju National University, Jeju 63243,

South Korea. ${ }^{2} \mathrm{Neo}$ Environmental Business Co., Dangjin-si,

Chungcheongnam-do, South Korea.

Received: 20 January 2017 Accepted: 6 July 2017

Published online: 25 July 2017

\section{References}

Ajiboye OO, Yakubu AF, Adams TE. A perspective on the ingestion and nutritional effects of feed additives in farmed fish species. World J Fish \& Marine Sci. 2012;4: $87-101$.

Anand PSS, Kumar S, Panigrahi A, Ghoshal TK, Dayal JS, Biswas G, et al. Effects of C:N ratio and substrate integration on periphyton biomass, microbial dynamics and growth of Penaeus monodon juveniles. Aquaculture Int. 2013; 21:511-24.

AOAC (Association of Official Analytical Chemists). Official Methods of Analysis. 16th ed. Association of Official Analytical Chemists; 1995.

Avnimelech Y. Carbon/nitrogen ratio as a control element in aquaculture systems. Aquaculture. 1999;176:227-35.

Avnimelech Y. Biofloc technology — a practical guide book. 2nd ed. Baton Rouge: The World Aquaculture Society; 2012.

Bauer W, Prentice-Hernández C, Tesser MB, Wasielesky W, Poersch LHS. Substitution of fishmeal with microbial floc meal and soy protein concentrate in diets for the pacific white shrimp Litopenaeus vannamei. Aquaculture. 2012;342-343:112-6.

Burford MA, Thompson PJ, McIntosh RP, Bauman RH, Pearson DC. The contribution of flocculated material to shrimp (Litopenaeus vannamei) nutrition in a high-intensity, zero-exchange system. Aquaculture. 2004; 232:525-37. 
Castex M, Lemaire P, Wabete N, Chim L. Effect of dietary probiotic Pediococcus acidilactici on antioxidant defences and oxidative stress status of shrimp Litopenaeus stylirostris. Aquaculture. 2009;294:306-13.

Castex M, Lemaire P, Wabete N, Chim L. Effect of probiotic Pediococcus acidilactici on antioxidant defences and oxidative stress of Litopenaeus stylirostris under Vibrio nigripulchritudo challenge. Fish Shellfish Immunol. 2010;28:622-31.

Crab R, Lambert A, Defoirdt T, Bossier P, Verstraete W. The application of bioflocs technology to protect brine shrimp (Artemia franciscana) from pathogenic Vibrio harveyi. J Appl Microbiol. 2010;109:1643-9.

Crab R, Defoirdt T, Bossier P, Verstraete W. Biofloc technology in aquaculture: beneficial effects and future challenges. Aquaculture. 2012;356-357:351-6.

Dantzler AS, Burnett KG, Burnett LE. Effects of hypercapnic hypoxia and respiratory burst inhibition on the bactericidal activity of hemocytes from the penaeid shrimp Litopenaeus vannamei. Am Zool. 2001;41:1422-3.

De Schryver P, Crab R, Defoirdt T, Boon N, Verstraete W. The basics of bioflocs technoloty: the added value for aquaculture. Aquaculture. 2008;277:125-37.

Ekasari J, Azhar MH, Surawidjaja EH, Nuryati S, De Schryver P, Bossier P. Immune response and disease resistance of shrimp fed biofloc grown on different carbon sources. Fish Shellfish Immunol. 2014;41:332-9.

Hari RE, Livingstone DM, Siber R, Burkhardt-Holm PA, Guettinger $\mathrm{H}$. Consequences of climatic change for water temperature and brown trout populations in Alpine rivers and streams. Glob Change Biol. 2006;12:10-26.

Haslun J, Correia E, Strychar K, Morris T, Samocha T. Characterization of bioflocs in a no water exchange super-intensive system for the production of food size pacific white shrimp Litopenaeus vannamei. Int J Aquacult. 2012; doi: 10.5376/ija.2012.02.0006

Hernández-López J, Gollas-Galván T, Vargas-Albores F. Activation of the prophenoloxidase system of the brown shrimp (Penaeus californiensis Holmes). Comp biochem phys C. 1996;113:61-6.

Jang IK, Pang Z, Yu J, Kim SK, Seo HC, Cho YR. Selectively enhanced expression of prophenoloxidase activating enzyme 1 (PPAE1) at a bacteria clearance site in the white shrimp, Litopenaeus vannamei. BMC Immunol. 2011;12:70.

Johnson CN, Barnes S, Ogle J, Grimes DJ, Chang YJ, Peacock AD, Kline L. Microbial community analysis of water, foregut, and hindgut during growth of pacific white shrimp, Litopenaeus vannamei, in closed-system aquaculture. J World Aquac Soc. 2008;39:251-8.

Ju ZY, Forster IP, Conquest L, Dominy W. Enhanced growth effects on shrimp (Litopenaeus vannamei) from inclusion of whole shrimp floc or floc fractions to a formulated diet. Aquacult Nutr. 2008;14:533-43.

Kent M, Browd CL, Leffler JW. Consumption and digestion of suspended microbes by juvenile Pacific white shrimp Litopenaeus vannamei. Aquaculture. 2011;319:363-8.

Kiessling A, Askbrandt S. Nutritive value of two bacterial strains of single-cell protein for rainbow trout (Oncorhynchus mykiss). Aquaculture. 1993;109:119-30.

Kuhn DD, Boardman GD, Lawrence AL, Marsh L, Flick GJ. Microbial floc meal as a replacement ingredient for fish meal and soybean protein in shrimp feed. Aquaculture. 2009;296:51-7.

Kuhn DD, Lawrence AL, Boardman GD, Patnaik S, Marsh L, Flick GJ. Evaluation of two types of bioflocs derived from biological treatment of fish effluent as feed ingredients for Pacific white shrimp, Litopenaeus vannamei. Aquaculture. 2010;303:28-33.

Lee BJ, Kim SS, Song JW, Oh DH, Cha JH, Jeong JB, Heo MS, Kim KW, Lee KJ. Effects of dietary supplementation of citrus by-products fermented with a probiotic microbe on growth performance, innate immunity and disease resistance against Edwardsiella tarda in juvenile olive flounder, Paralichthys olivaceus (Temminck \& Schlegel). J Fish Dis. 2013;36:617-28

Li P, Gatlin DM. Dietary brewers yeast and the prebiotic Grobiotic ${ }^{T M}$ AE influence growth performance, immune responses and resistance of hybrid striped bass (Morone chrysops $\times M$. saxatilis) to Streptococcus iniae infection. Aquaculture. 2004;231:445-56.

Li J, Tan B, Mai K. Dietary probiotic Bacillus OJ and isomaltooligosaccharide influence the intestine microbial populations, immune responses and resistance to white spot syndrome virus in shrimp (Litopenaeus vannamei). Aquaculture. 2009;291:35-40.

Liu $\mathrm{CH}$, Chen JC. Effect of ammonia on the immune response of white shrimp Litopenaeus vannamei and its susceptibility to Vibrio alginolyticus. Fish Shellfish Immunol. 2004;16:321-34.

Paglia DE, Valentine WN. Studies on the quantitative and qualitative characterization of erythrocyte glutathione peroxidase. Transl Res. 1967;70: 158-69.
Parrilla-Taylor DP, Zenteno-Savín T. Antioxidant enzyme activities in Pacific white shrimp (Litopenaeus vannamei) in response to environmental hypoxia and reoxygenation. Aquaculture. 2011;318:379-83.

Robertson L, Bray W, Leung-Truillo J, Lawrence A. Practical molt staging of Penaeus setiferus and Penaeus stylirostris. J World Aquac Soc. 1987;18:180-5.

Siwicki AK, Anderson DP, Rumsey GL. Dietary intake of immunostimulants by rainbow trout affects non-specific immunity and protection against furunculosis. Vet Immunol Immunop. 1994;41:125-39.

Stokstad E. Down on the shrimp farm. Science. 2010;328:1504-5.

Vazquez L, Alpuche J, Maldonado G, Agundis C, Pereyra-Morales A, Zenteno E. Review: immunity mechanisms in crustaceans. Innate Immun. 2009;15:179-88.

Wang YB. Effect of probiotics on growth performance and digestive enzyme activity of the shrimp Penaeus vannamei. Aquaculture. 2007;269:259-64.

Wasielesky W, Atwood H, Stokes A, Browdy CL. Effect of natural production in a zero exchange suspended microbial floc based super-intensive culture system for white shrimp Litopenaeus vannamei. Aquaculture. 2006;258:396-403.

Wongsasak U, Chaijamrus S, Kumkhong S, Boonanuntanasarn S. Effects of dietary supplementation with $\beta$-glucan and synbiotics on immune gene expression and immune parameters under ammonia stress in Pacific white shrimp. Aquaculture. 2015;436:179-87.

Xu WJ, Pan LQ, Zhao DH, Huang J. Preliminary investigation into the contribution of bioflocs on protein nutrition of Litopenaeus vannamei fed with different dietary protein levels in zero-water exchange culture tanks. Aquaculture. 2012;350-353:147-53.

Xu WJ, Pan LQ. Effects of bioflocs on growth performance, digestive enzyme activity and body composition of juvenile Litopenaeus vannamei in zero-water exchange tanks manipulating C/N ratio in feed. Aquaculture. 2012;356-357:147-52.

Xu WJ, Pan LQ. Enhancement of immune response and antioxidant status of Litopenaeus vannamei juvenile in biofloc-based culture tanks manipulating high C/N ratio of feed input. Aquaculture. 2013;412-413:117-24.

Zhao P, Huang J, Wang XH, Song XL, Yang CH, Zhang XG, et al. The application of bioflocs technology in high-intensive, zero exchange farming systems of Marsupenaeus japonicus. Aquaculture. 2012;354-355:97-106.

\section{Submit your next manuscript to BioMed Central and we will help you at every step:}

- We accept pre-submission inquiries

- Our selector tool helps you to find the most relevant journal

- We provide round the clock customer support

- Convenient online submission

- Thorough peer review

- Inclusion in PubMed and all major indexing services

- Maximum visibility for your research

Submit your manuscript at www.biomedcentral.com/submit
( Biomed Central 